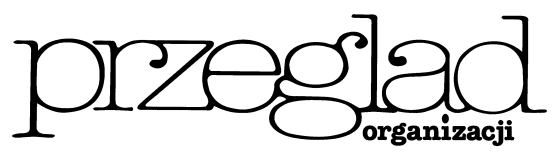

\title{
Humanistyczno-ekonomiczne uwarunkowania zarządzania jakością
}

https://doi.org/10.33141/po.2005.11.11

Radosław Wolniak

\section{Wprowadzenie}

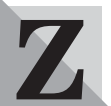

arządzanie jest nauką interdyscyplinarną. Jest dyscypliną zaliczaną do grupy nauk ekonomicznych, ale w swej praktyce czerpie także w dużym stopniu z „twardych” nauk inżynieryjnych oraz z nauk „miękkich”, czyli humanistycznych. Z jednej strony zarządzanie powinno starać się wyrazić opisywany świat w ścisłych liczbowych kategoriach, ale z drugiej, jego głównym przedmiotem zainteresowań sa ludzie, ich działanie, motywacja itp. Można stwierdzić, że dobre, skuteczne i efektywne zarządzanie nie jest możliwe w oderwaniu od ludzi. Mimo drastycznego rozwoju technologii, coraz szerszego wykorzystania komputerów i pracy maszynowej, to ciaggle człowiek, jego twórczość, pomysły, intuicja i inicjatywa decydują o sukcesie firmy. $Z$ tego właśnie powodu w koncepcji zarządzania jakością, a zwłaszcza w najbardziej rozwiniętym podejściu TQM - Totalnego Zarządzania Jakością aspekty humanistyczne stanowią podstawowy czynnik decydujący o powodzeniu wdrażania tej koncepcji.

Jednakże problemy związane z ludźmi nie mogą być w zarządzaniu, tak jak ma to miejsce w naukach humanistycznych, rozpatrywane w oderwaniu od ekonomicznych efektów działalności. W organizacji należy zawsze pamiętać, że celem zarządzających jest zapewnienie jej przetrwania na rynku i pozytywnych efektów ekonomicznych. Dobra atmosfera w zespole, wysoka motywacja i zadowolenie pracowników nie mogą być osiągane kosztem wyników ekonomicznych, ponieważ doprowadziłoby to do upadku firmy. Ekonomiczna efektywność i zdolność do osiągania długookresowego zysku są bardzo ważnymi parametrami, koniecznymi do tego, aby organizacja mogła przetrwać na rynku. Organizacja nie może także funkcjonować bez podsystemu technicznego: maszyn, urządzeń, surowców, podzespołów, stosowanych technologii itp. Bez nich stanie się nienowoczesna, przestarzała i nie będzie w stanie produkować, wytwarzać ani świadczyć usług wysokiej jakości.

Dlatego też istnieje konieczność połączenia wszystkich obszarów zarządzania (humanistycznego, ekonomicznego i technicznego) $\mathrm{w}$ jeden, sprawnie funkcjonujący system, w którym to systemie nastąpi wzajemne, pozytywne sprzężenie zwrotne pomiędzy wzrostem zadowolenia i zaangażowania pracowników a efektywnością i wynikami ekonomicznymi firmy. Aby organi-
Przegląd Organizacji, Nr 11 (790), 2005, ss. 41-45 www.przegladorganizacji.pl Towarzystwo Naukowe Organizacji i Kierownictwa (TNOiK) zacja zachowywała wysoką jakość we wszystkich swoich działaniach, musi skupić się na trzech obszarach działalności (rysunek 1):

- sferze technicznej (maszyny, urządzenia, surowce, półfabrykaty, podzespoły, „mierzalna” jakość produktu),

- sferze ekonomicznej (zysk, przychód, wielkość sprzedaży, efektywność),

- sferze humanistycznej (zarządzanie ludźmi w organizacji ukierunkowane na jakość).

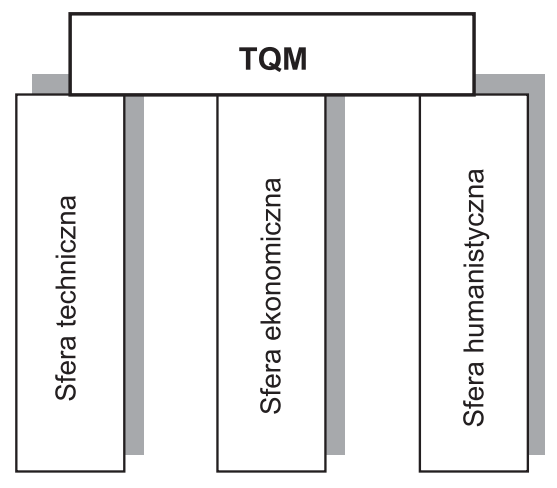

Rys. 1. Elementy TQM

Źródło: opracowanie własne.

\section{Składniki humanistyczne Totalnego Zarządzania Jakością}

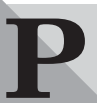

roblematyka zarządzania zasobami ludzkimi jest obecna we wszystkich koncepcjach zarządzania jakością. Przy czym bezpośrednio w normach serii ISO 9000:2000 (normy ISO 9001 i ISO 9004) potraktowana została drugoplanowo ${ }^{1)}$. Prawdziwie pełne znaczenie wagi pracowników i ich potencjału zostało docenione dopiero w koncepcji TQM. Kompleksowe zarządzanie jakością jest podejściem holistycznym, zwracającym uwagę na wszystkie możliwe aspekty organizacyjne. Aby skutecznie wdrażać tę filozofię, należy zidentyfikować i zbudować powiązania pomiędzy ludźmi w organizacji. Już Deming stwierdził, że przyczyną 80\% problemów z jakością w organizacji jest złe zarządzanie i organizacja pracy. Dlatego w celu doskonalenia jakości w przedsiębiorstwie należy uwzględnić w zarządzaniu różne aspekty humanistyczne, pozwalające na poprawę efek- 
tywności i skuteczności jej funkcjonowania. Do najważniejszych wśród różnych, humanistycznych składników TQM można zaliczyć następujące elementy (rysunek 2):

- kulturę (narodową i organizacyjną) [3, 13, 23] ${ }^{2)}$,

- motywację pracowników [3, 8, 21, 22, 31, 34],

- zarządzanie wiedzą - szkolenia [4, 23, 26],

- komunikację interpersonalna [6, 23, 28],

- pracę zespołową [6, 28, 31],

- etykę biznesu [2, 5, 27].

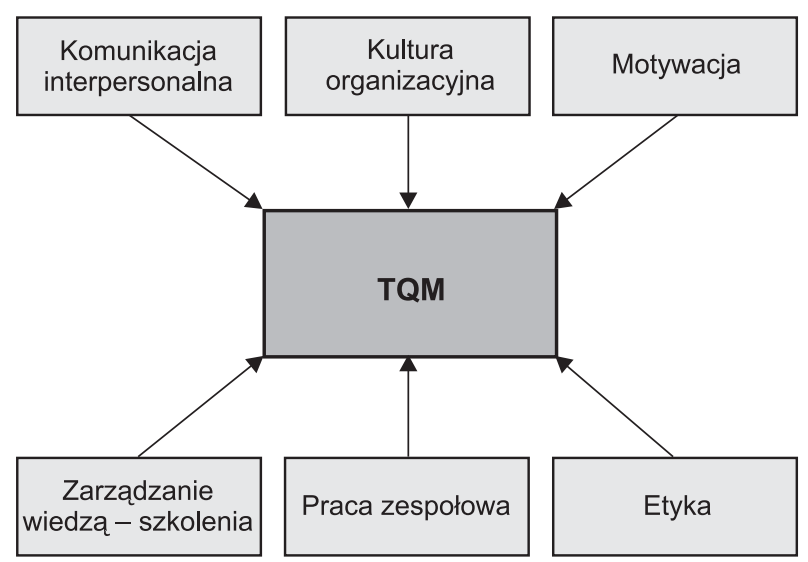

Rys. 2. Humanistyczne składniki TQM

Źródło: opracowanie własne.

Pierwszym elementem, który musi zostać uwzględniony w budowie efektywnego systemu zarzadzania organizacją, jest jej kultura organizacyjna. Istnieje wiele definicji kultury ${ }^{3)}-\mathrm{w}$ szerszym sensie kulture można zdefiniować jako cywilizację, czyli złożoną całość, która obejmuje wiedzę, wierzenia, sztukę, moralność, prawa, obyczaje oraz inne zdolności i nawyki nabyte przez ludzi jako członków społeczeństwa [17]. W węższym sensie kulturę organizacyjną definiuje się jako zestaw wartości, które pomagają członkom danej organizacji rozumieć, za czym organizacja się opowiada, jak pracuje i co uważa za ważne [6].

Kultura kraju, w jakim dana organizacja się znajduje, niewątpliwie w dużym stopniu wpływa na kulturę działających w nim przedsiębiorstw. W czasach, gdy nie istniały organizacje międzynarodowe ${ }^{4}$, problem był mniejszy, ponieważ wtedy kultura danego społeczeństwa determinowała kulturę poszczególnych przedsiębiorstw. W tamtych czasach kulturę przedsiębiorstwa można było określić jako podzbiór kultury kraju (rysunek 3). Jednakże coraz powszechniejsza globalizacja i powstanie korporacji międzynarodowych zmieniło ten prosty obraz. Obecnie stosunki między kulturami narodowymi a kulturami poszczególnych organizacji stały się dużo bardziej skomplikowane. W jednej firmie mogą na przykład pracować ludzie z różnych regionów świata, wychowani w odmiennych uwarunkowaniach kultury narodowej. $\mathrm{Na}$ postępowanie, motywacje, wartości pracowników wpływają obydwie kultury z różną siłą oddziaływania w zależności od konkretnej sytuacji (rysunek 3).

Różnicę między kulturą kraju a kulturą organizacji można przedstawić w sposób następujący [5]: kultura kraju - wyróżnia poszczególnych ludzi, ich grupy oraz organizacje w różnych krajach;

- kultura organizacyjna - pozwala na rozróżnianie poszczególnych organizacji działających na terenie danego kraju.

\section{PRZED OKRESEM GLOBALIZACJI}

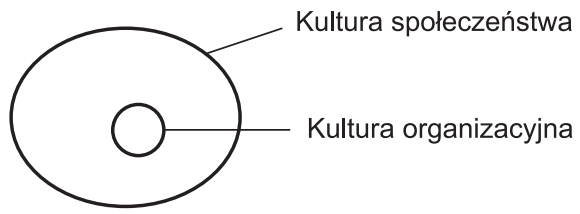

OBECNIE

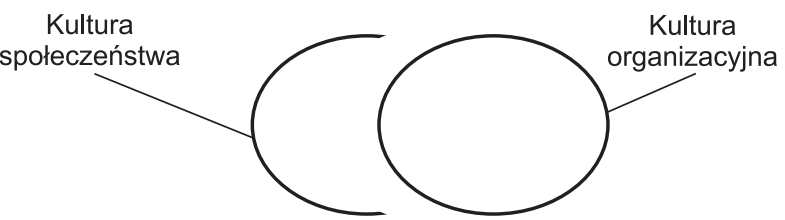

Rys. 3. Związki między kulturą organizacyjną a kulturą kraju

Źródło: [13].

Kultura organizacyjna wywiera bardzo istotny wpływ na zarządzanie jakością. Sposób postępowania, myślenia, zachowania się mieszkańców poszczególnych krajów bardzo często istotnie determinuje możliwości wdrażania TQM i innych projakościowych koncepcji zarządzania w danym kraju ${ }^{5}$. Jeśli w jakimś kraju kultura organizacyjna nie sprzyja zarzadzaniu jakością (niechęć do podejścia zespołowego, duży dystans władzy itp.), to bardzo trudno jest ją zmienić, ponieważ wymaga to wiele czasu' ${ }^{6}$.

Tworzenie projakościowej kultury organizacyjnej łączy się z pojęciem pracy zespołowej ${ }^{7)}$. Pracę zespołowa można nazwać „,sercem” prawidłowo wdrażanej filozofii TQM. W wyniku pracy zespołowej ludzie mogą, dzięki występowaniu efektu synergii, osiągnąć więcej niż w przypadku prostej sumy indywidualnych wysiłków. Każdy zespół powinien być nastawiony na współpracę, dzielenie się pomysłami i wzajemną pomoc.

Praca zespołowa powinna dawać zadowolenie każdemu z jego uczestników. Nikt w zespole nie powinien być dyskryminowany. Dobry zespół to nie zespół zawsze zgadzający się ze swoim liderem, ale taki zespół, który pozwala generować interesujące twórcze pomysły. Skutecznie działający zespół pozwala na uzyskanie lepszych rezultatów w porównaniu $\mathrm{z}$ indywidualnym podejściem.

Kolejnym, humanistycznym czynnikiem zarządzania, niezbędnym podczas wdrażania filozofii TQM jest odpowiednia motywacja pracowników. Wysoka jakość i dobra obsługa klienta wiążą się nieodłącznie z dobrą praca pracowników. Jednakże pracownik, aby dobrze pracował, musi mieć do tego odpowiednią motywację. Motywacja zajmuje się czynnikami wpływajacymi na ludzi, aby zachowywali się w określony sposób. Można wyróżnić jej trzy składniki: kierunek (określający, 
co dana osoba stara się zrobić), wysiłek (decydujący o tym, jak bardzo się stara) i wytrwałość (mówiąca o tym, jak długo dana osoba będzie się starać) [20]. Motywacja obejmuje siły (cele i wyniki) tkwiące w człowieku lub na niego oddziałujące. Czynniki te inicjuja i kierują jego zachowaniem [25].

Dobrze umotywowani pracownicy lepiej wykonuja swe obowiązki, w lepszy sposób traktują klienta, są bardziej twórczy, praca daje im przyjemność i satysfakcję. Motywacja jest tym czynnikiem zarządzania, który w sposób najbardziej bezpośredni wiąże kierowników z podwładnymi. Skuteczność menedżera zależy w bezpośredni sposób od jego umiejętności przywódczych, a więc także od jego zdolności motywowania pracowników. Bez odpowiedniego systemu motywacji nie można zapewnić właściwego przywództwa w organizacji, a co za tym idzie nie można doprowadzić do sytuacji, w której pracownicy wykonują dokładnie i skutecznie potrzebne zadania. System motywacji jest niezbędny, aby dało się wprowadzać filozofię TQM. Nie można bowiem osiagnaćc odpowiedniego zaangażowania ludzi, jeśli nie będą oni odpowiednio umotywowani do pracy.

W celu zapewnienia wysokiej motywacji pracowników, a co za tym idzie wysokiej jakości ich pracy należy stosować różnorodne narzędzia motywacji. Najogólniej środki motywacji można podzielić na finansowe i pozafinansowe. Przy czym na motywację finansową składają się płaca zasadnicza oraz wszelkiego rodzaju premie i dodatki, natomiast na motywację pozafinansową składają się takie środki, jak między innymi: wyróżnienia, nagrody, awanse, pochwały, dodatkowy czas wolny itp. W zależności od kultury przedsiębiorstwa, czy postaw życiowych pracowników różne środki motywacji mogą odgrywać mniejszą lub większą rolę. Na przykład w Polsce stosunkowo ważna jest motywacja finansowa, podczas gdy w krajach o wyższym standardzie życia coraz ważniejsze stają się środki pozafinansowe zaspokajające potrzeby uznania i samorealizacji ${ }^{8}$.

Następnym, niezwykle istotnym obszarem, jaki musi zostać uwzględniony przez współczesne zarządzanie jakością, jest problematyka zarządzania wiedzą. Wiedza jest dziś tak istotna, że bywa dodawana w teorii ekonomii jako czwarty zasób ${ }^{9}$. Zarządzanie wiedzą można zdefiniować jako ogół procesów umożliwiających tworzenie, upowszechnianie i wykorzystanie wiedzy do realizacji celów organizacji [31]. Zarządzanie wiedzą jest procesem, w wyniku którego organizacja generuje wartość opartą na majątku intelektualnym. Zwykle ten proces generowania wartości wymaga dzielenia się wiedzą między ludźmi, komórkami organizacyjnymi i firmami [10].

Ważnym elementem humanistycznym w zarządzaniu jest także etyka biznesu. Etyka jest to nauka filozoficzna, która formułuje ogólne zasady moralne oraz szczegółowe normatywy ludzkiego działania za pomoca wrodzonych człowiekowi zdolności poznawczych [33]. Etyka biznesu adaptuje metody i cele etyki normatywnej, dostosowujac je do konkretnych przypadków i wymagań związanych z problemami moralnymi występującymi w działalności gospodarczej [27]. Etyka biznesu zajmuje się oceną i określaniem standardów moralnych przystających do konkretnej sfery współ- czesnego społeczeństwa - działalności gospodarczej [27].

Nauka ta próbuje badać, w jaki sposób polityka i działania podejmowane przez przedsiębiorstwa wpływaja na dobro ludzi z jego otoczenia. Etyka odwołuje się do określanych standardów moralnych i z tego punktu widzenia próbuje do działalności gospodarczej wprowadzić nową perspektywę. Ocenia ona postępowanie ludzi i przedsiębiorstw w procesie zarządzania z punktu widzenia przyjętych założeń i standardów moralnych. Formułuje także wytyczne, w jaki sposób należy postępować zarządzając organizacjami, żeby z jednej strony realizować cele gospodarcze, a z drugiej strony nie łamać norm etycznych.

Prawidłowo funkcjonujacy system zarządzania jakością nie jest także możliwy bez zapewnienia właściwej komunikacji interpersonalnej wewnątrz organizacji oraz pomiędzy organizacją a jej partnerami rynkowymi (klientami i dostawcami). Komunikacja interpersonalna jest takim czynnikiem, który warunkuje prace zespołu i efektywne zarządzanie [28]. Efektywne zarządzanie ludźmi w organizacji wymaga dobrej komunikacji interpersonalnej. Istotnym elementem TQM jest przywództwo. Jednakże, aby zapewnić właściwe przywództwo, trzeba potrafić komunikować się z pracownikami. Jeśli pracownicy nie rozumieja poleceń i sugestii przekazywanych im przez kierownictwo, nic nie będzie nawet $\mathrm{z}$ najlepszych planów i strategii działania organizacji. Także dobra atmosfera i osiagnięcie zrozumienia w zespole wymaga skutecznej komunikacji. Tymczasem w praktyce każdy proces komunikacji jest zakłócany przez wiele różnorodnych barier (które trzeba zidentyfikować i co najważniejsze, których istnienia należy być świadomym), mogących utrudnić lub wręcz uniemożliwić ten proces.

\section{Elementy humanistyczne a wynik ekonomiczny}

W pierwszej chwili może wydawać się, że omawiane humanistyczne aspekty zarządzania nic przedsiębiorstwu nie dają z punktu widzenia osiągania zysków i ekspansji rynkowej. Pozornie może się wydawać, że generują tylko straty. Motywacja finansowa czy pozafinansowa wiąże się z ponoszeniem kosztów, podobnie jak ma to miejsce w przypadku szkoleń. Postępowanie etyczne wiąże się często $\mathrm{z}$ rezygnacją $\mathrm{z}$ zysków, jeśli są one osiągane $\mathrm{w}$ sposób niezgodny $\mathrm{z}$ wyznawanym systemem wartości. Także budowa dobrego systemu motywacji, kultury organizacyjnej czy tworzenie warunków do pracy zespołowej wymaga niewątpliwie znacznego wysiłku.

Możemy zadać sobie pytanie, czy wysiłek ten i koszty rzeczywiście się opłacają i czy prowadzą do poprawy wyniku finansowego organizacji. Wszystko zależy od konkretnego przypadku i jeśli przesadzi się np. z premiami czy szkoleniami, może to zakłócić płynność finansową firmy i doprowadzić do kłopotów. Jednakże zwykle prawidłowe zarządzanie elementami humanistycznymi powoduje poprawę funkcjonowania firmy i pozytywnie oddziałuje na jej wyniki finansowe i efektywność. 


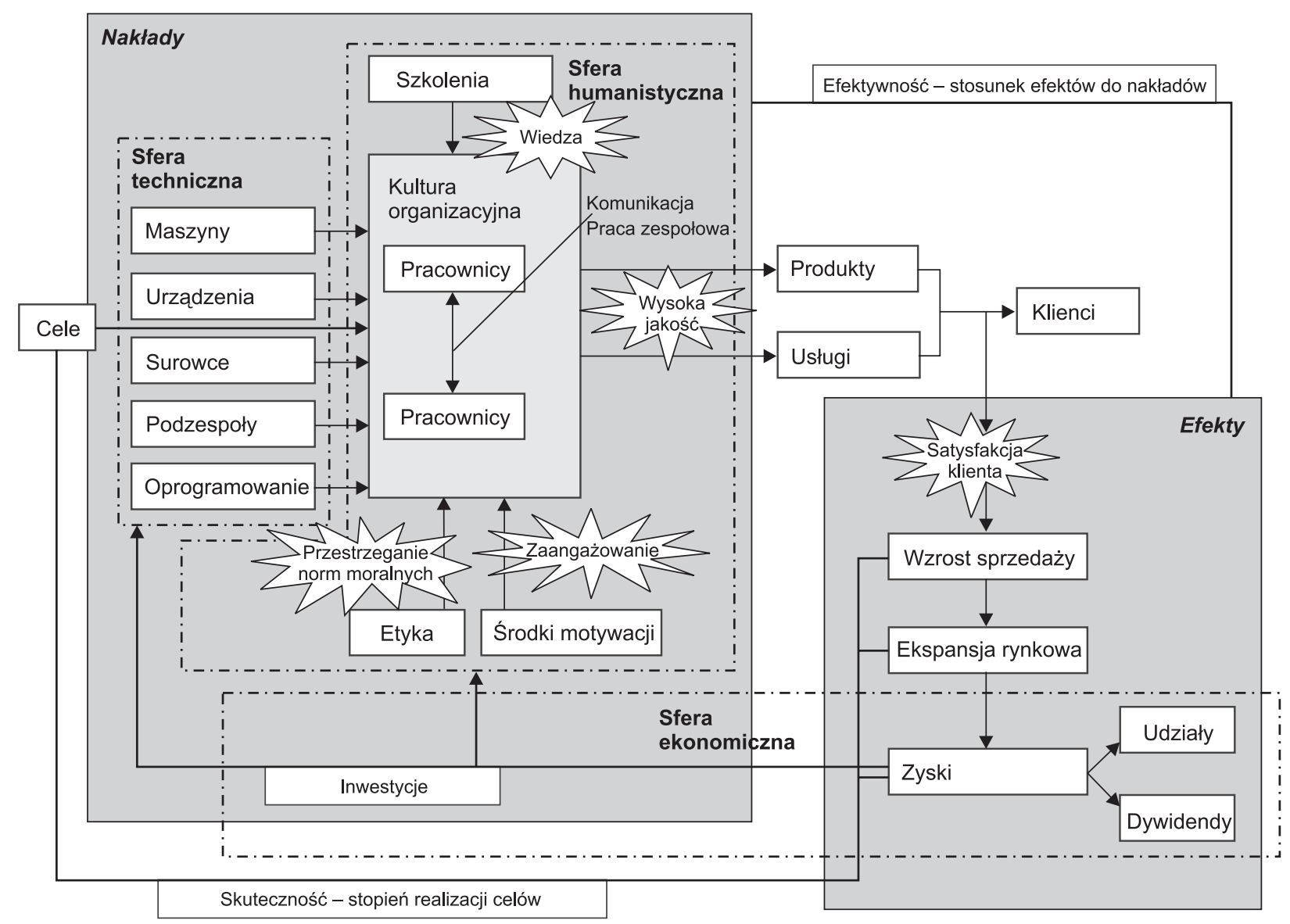

Rys. 4. Model związków humanistycznych, ekonomicznych i technicznych aspektów funkcjonowania organizacji

Źródło: opracowanie własne.

Mechanizm ten został przedstawiony na rysunku 4. Sfera techniczna to zasoby, które znajdują się „na wejściu” procesu produkcyjnego czy usługowego. Maszyny i urządzenia, sprzęt komputerowy, oprogramowanie, surowce, podzespoły, materiały itp. elementy są wykorzystywane w procesie produkcji lub świadczenia usług przez pracowników, którzy starają się zaspokoić potrzeby klientów. Jednakże, aby pracownicy dobrze pracowali, muszą oni posiadać odpowiednią wiedzę i umiejętności. Dzięki motywacji uzyskuje się zaangażowanie pracowników; w wyniku szkoleń pracownicy zdobywają niezbędną wiedzę. Poprzez kształtowanie norm etycznych pracownicy starają się zawsze postępować zgodnie z wpojonym im kanonem wartości, a więc np. nie będą podejmować działań na szkodę własnej organizacji. Wreszcie komunikacja interpersonalna czy praca zespołowa usprawniają i pozwalają lepiej zorganizować pracę.

Tacy pracownicy - zaangażowani w działania firmy, dysponujący dużą wiedzą i umiejętnościami, utożsamiający się z celami organizacji i umiejący wzajemnie współpracować, będą w stanie zapewnić wysoką jakość $\mathrm{i}$ taki poziom obsługi klienta, aby był on $\mathrm{z}$ tego procesu zadowolony. Zadowolony klient wraca do firmy i ponownie kupuje oferowane produkty i usługi. Prowadzi to do wzrostu sprzedaży, w wyniku czego firma poprawia swoją pozycję na rynku i może wygrać walkę z konkurentami. Wzrost sprzedaży i dobra pozycja rynkowa pozwalają osiągać wysokie zyski, które mogą być inwestowane w nowe środki techniczne i wydatkowane na poprawe sfery humanistycznej. Z rysunku widać także, że model zapewnia jednocześnie wysoką skuteczność - dzięki realizacji zaplanowanych „na wejściu” do procesu celów oraz wysoką efektywność, ponieważ uzyskuje się korzystny stosunek efektów do włożonych nakładów.

\section{Podsumowanie}

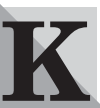

ażde przedsiębiorstwo, aby efektywnie i skutecznie działać na rynku, musi zapewnić sobie wystarczającą do przetrwania ilość środków finansowych. Dawniej dobre wyniki i wysoką sprzedaż można było osiagnać poprzez niska cenę oferowanych produktów. Jednakże obecnie takie podejście już nie wystarcza. Nie znaczy to, że cena nie jest ważna, ale sama niska cena bez wysokiej jakości produktu nie jest $\mathrm{w}$ stanie zapewnić, że firma w długim okresie będzie w stanie utrzymać się na rynku i generować zyski. Dlatego też tak duża rola wysokiej jakości produktów i usług.

Jednakże jakość nie może być rozumiana w sposób techniczny tylko i wyłącznie jako zbiór określonych, z góry założonych parametrów, jakie ma posia- 
dać dany produkt czy też usługa. Jakość to cały system interakcji na linii klient - organizacja oraz pomiędzy klientami wewnętrznymi. Interakcje te muszą być tak zorganizowane, aby zapewnić maksymalną efektywność całego procesu. Można to osiagnąć dzięki silnemu uwzględnieniu w procesie zarządzania elementów humanistycznych: kultury organizacyjnej, motywacji, komunikacji interpersonalnej, zarządzania wiedzą, pracy zespołowej oraz etyki i połączeniu ich z elementami ekonomicznymi i technicznymi w jeden spójnie działający system.

Przedstawiony model powiązań między wymienionymi sferami zarządzania pokazuje, że elementy humanistyczne są bardzo ważne i bez nich praktycznie menedżerowie nie są w stanie sprawnie zarządzać żadną organizacją. Natomiast w wyniku dbania o sferę humanistyczną nie tylko uzyskuje się większe zadowolenie pracowników i klientów, ale także poprawę wyników ekonomicznych przedsiębiorstwa. dr inz. Radostaw Wolniak Wydział Organizacji i Zarządzania Katedra Zarządzania Jakością Procesów i Produktów Politechniki Śląskiej

\section{PRZYPISY}

1) Na przykład w normie ISO 9001:2000 problemom zarządzania zasobami ludzkimi jest poświęcony punkt 6.2 tej normy [9].

2) Na temat kultury organizacyjnej w zarządzaniu jakością zobacz: [3, 18].

3) Słowo kultura wywodzi się z języka łacińskiego, od terminu cultura, który oznacza uprawę roli, sposób uprawy, zabiegi pielęgnacyjne, ćwiczenie, doskonalenie, poprawę zdolności [13]. Także obecnie ciagle jeszcze tego słowa używa się w rolnictwie w pierwotnym znaczeniu, co można zaobserwować w takich zwrotach, jak: kultura rolna, kultura bakterii, bądź monokultura. Po raz pierwszy w nowym znaczeniu termin ten został użyty przez Cycerona, który w dziele Disputationes Tusculanae użył sformułowania cultura animi (dosłownie: uprawa umystu).

4) A przynajmniej nie miały tak dużego oddziaływania jak dzisiaj, bo formalnie rzecz ujmując zawsze istniały międzynarodowe organizacje, działające w różnych kulturach jednocześnie, nawet w czasach starożytnych, np. pierwsze banki działające na terenie starożytnej Mezopotamii, Egiptu, państwa Hetytów i Mittanii.

5) Na przykład uważa się, że japońska kultura lepiej sprzyja pracy zespołowej, podczas gdy na przykład amerykańska jest skuteczniejsza w zakresie promowania indywidualnych osiągnięć i budzenia „ducha” rywalizacji między pracownikami. Porównaj [10, 13$]$.

6) Przynajmniej tak się zwykle przyjmuje. Niektórzy autorzy jednakże się z tym nie zgadzają, uważając, że zmiany kulturowe mogą być wprowadzane szybko zarówno w krajach, jak i w organizacjach - porównaj [18].

7) Zespół można zdefiniować jako grupę pracowników występujących jako jednostka, często nadzorowaną tylko w niewielkim stopniu lub wcale, której zadaniem jest wykonywanie funkcji organizacyjnych [6]. Zwartość grupy wskazuje na siłę wpływu grupy jako całości na poszczególnych członków [31]. Zespoły zadaniowe - zespoły powoływane do rozwiazywania określonego problemu lub zajęcia się zadaniem. Istnieją do czasu zakończenia zadania lub rozwiązania problemu [31].

8) Porównaj na przykład [34].

9) Obok tradycyjnych zasobów, czyli ziemi, pracy i kapitału. BIBLIOGRAFIA

[1] ANSELL T., Zarzadzanie jakościa $w$ sektorze ustug finansowych, Związek Banków Polskich, Warszawa 1997.
[2] CHMIELECKI A., Rzeczy i wartości. Humanistyczne podstawy edukacji ekonomicznej, PWN, Warszawa 1999.

[3] DAHLGAARD J. J., KRISTENSEN K., KANJI G. K., Podstawy zarzadzania jakościa, PWN, Warszawa 2000.

[4] FAZLAGIĆ A., Geneza i perspektywy zarzadzania wiedza, „Problemy Jakości”, nr 10, 2002, s. 26-30.

[5] FRYZEモ B., Etyka a jakość pracy, [w:] Zmieniajace sie przedsiębiorstwo $w$ zmieniajacej sie politycznie Europie.

Tom 6: Determinanty jakości a efektywność procesów, Kraków 2003, s. 171-187.

[6] GRIFFIN R.W., Podstawy zarzadzania organizacjami, PWN, Warszawa 2002.

[7] HEMMI V.J., Geben Sie Total Quality Management zweite Chance, „New Management”, nr 4, 2003, s. 52-57.

[8] HERZBERG F., MAUSNER B., SYNDERMAN B., The Motivation to Work, Wiley, New York 1959.

[9] ISO 9001:2000. Systemy zarzadzania jakościa. Wymagania.

[10] Knowledge Management, http://www.cio.com/research/ knowledge/edit/kmabcs.html\#what

[11] Komunikacja w twojej firmie, http://www.openlearning.pl/pl/szkolenia/internetowe/firma/komunikacja-w-organizacji.html

[12] Komunikacja,http://pl.wikipedia.org/wiki/Komunikacja [13] KORPANTY J., Stownik tacinsko-polski, PWN, Warszawa 2001.

[14] KRZEMIEŃ E., WOLNIAK R., Kulturowe uwarunkowania zarzadzania jakościa, konferencja naukowa Rola towaroznawstwa $w$ zarzadzaniu jakościa $w$ warunkach gospodarki opartej na wiedz, Radom 2004.

[15] KRZEMIEŃ E., WOLNIAK R., Zarzadzanie jakościa $w$ sektorze ustug finansowych, Wydawnictwo Wyższej Szkoły Bankowości i Finansów, Bielsko-Biała 2004.

[16] Kultura organizacyjna, http://www.p-soft.pl/page.php?hr_5

[17] Kultura, http://pl.wikipedia.org/wiki/Kultura

[18] LOCK D., Podręcznik zarzadzania jakościa, PWN, Warszawa 2002.

[19] ŁAŃCUCKI J., Podstawy kompleksowego zarzadzania jakościa TQM, AE, Poznań 2001.

[20] MACIEJEWSKA M., Nie tylko pieniqdze. Motywowanie - zasady i korzyści, Wydawnictwo Personalne, Warszawa 1999.

[21] MASLOW A., Motywacja a osobowość, PAX, Warszawa 1990.

[22] McGREGOR D., The Human Side of Enterprise, McGraw-Hill, New York 1959.

[23] McKENNA E., BEECH N.,Zarzadzanie zasobami ludzkimi, Gebethner i Ska, Warszawa 1997.

[24] MUDIE P., COTTAM A., Ustugi. Zarzadzanie i marketing, PWN, Warszawa 1998.

[25] OLEKSYN T., Motywacja a płaca, „Personel”, nr 9, 1995.

[26] PAWLAK W. R., Zarzadzanie wiedza, czyli nowe wyzwania, „Problemy Jakości”, nr 10, 2001.

[27] PRATLEY P., Etyka w biznesie, Gebethner i Ska, Warszawa 1998.

[28] RZESZUTEK M., System jakości a zarzadzanie zasobami ludzkimi, „Problemy Jakości” 1998, nr 6, s. 7-16.

[29] SALEGNA G., FAZEL F. Obstacles to Implementing Quality, „Quality Progress”, nr 6, 2000.

[30] SMITH G.F., Too Many Types of Quality Problems, „Quality Progress”, nr 4, 2000.

[31] STONER J.A.F., FREEMAN R.E., GILBERT D.G. Jr., Kierowanie, PWE, Warszawa 2001.

[32] STROJNY M., Knowledge Management czyli o potrzebie "nowego zarzadzania" w warunkach gospodarki opartej na wiedzy, [w:] Zarzadzanie wiedza, Oficyna Wydawnicza Stowarzyszenia na rzecz Rozwoju Nauki Polskiej, KrakówKatowice 2001, s. 42-62.

[33] ŚLIPKO T., Zarys etyki ogólnej, WAM 2002.

[34] WOLNIAK R., Motywacja w systemie zarzadzania jakościa ustug, „Problemy Jakości”, nr 2, 2005. 